\title{
Complete mitochondrial genome of the lappet moth, Kunugia undans (Lepidoptera: Lasiocampidae): genomic comparisons among macroheteroceran superfamilies
}

\author{
Min Jee Kim, Jun Seong Jeong, Jong Seok Kim, Su Yeon Jeong and Iksoo Kim \\ Department of Applied Biology, College of Agriculture \& Life Sciences, Chonnam National University, \\ Gwangju, Republic of Korea.
}

\begin{abstract}
The mitochondrial genome (mitogenome) characteristics of the monotypic Lasiocampoidea are largely unknown, because only limited number of mitogenomes is available from this superfamily. In this study, we sequenced the complete mitogenome of the lappet moth, Kunugia undans (Lepidoptera: Lasiocampidae) and compared it to those of Lasiocampoidea and macroheteroceran superfamilies (59 species in six superfamilies). The 15,570-bp K. undans genome had one additional $\operatorname{trn} R$ that was located between $\operatorname{trn} A$ and $\operatorname{trn} N$ loci and this feature was unique in Macroheterocera, including Lasiocampoidea. Considering that the two $\operatorname{trn} R$ copies are located in tandem with proper secondary structures and identical anticodons, a gene duplication event might be responsible for the presence of the two tRNAs. Nearly all macroheteroceran species, excluding Lasiocampoidea, have a spacer sequence (1-34 bp) at the $t r n S_{2}$ and $N D 1$ junction, but most lasiocampid species, including $K$. undans, have an overlap at the trnS $S_{2}$ and ND1 junction, which represents a different genomic feature in Lasiocampoidea. Nevertheless, a TTAGTAT motif, which is typically detected in Macroheterocera at the $\operatorname{trn} S_{2}$ and ND1 junction, was also detected in all Lasiocampoidea. In summary, the general mitogenome characteristics of Lasiocampoidea did not differ greatly from the remaining macroheteroceran superfamilies, but it did exhibit some unique features.
\end{abstract}

Keywords: Kunugia undans, mitochondrial genome, Lasiocampoidea, Macroheterocera.

Received: November 17, 2016; Accepted: February 25, 2017.

\section{Introduction}

The typical metazoan mitochondrial genome (mitogenome) consists of 13 protein-coding genes (PCGs), 22 tRNAs, two rRNAs, and a major non-coding sequence referred to as the $\mathrm{A}+\mathrm{T}$-rich region. The characteristic features of the mitogenome (e.g., fast evolution, low recombination rates, and multiple copies per cell) are considered beneficial in several biological fields (Cameron, 2014). In particular, whole mitogenome sequences have been utilized for phylogenic analyses of several insect lineages (Dowton et al., 1997; Kim et al., 2011; Lu et al., 2013; Mao et al., 2014, 2015; Timmermans et al., 2014), and genomic characteristics have also been scrutinized to understand phylogenetic and evolutionary features of given taxonomic groups (Cameron and Whiting, 2008; Wan et al., 2013; Kim et al., 2014).

Mitogenome sequences in insects have been compiled in nearly 1,000 species that represent all insect orders and the Lepidoptera. As one of the four most species-rich

Send correspondence to Iksoo Kim. Department of Applied Biology, College of Agriculture \& Life Sciences, Chonnam National University, Gwangju 61186, Republic of Korea. E-mail: ikkim81@chonnam.ac.kr. insect orders, Lepidoptera is represented by 338 mitogenomes in GenBank (last visited on August 14, 2016), including 37 nearly complete sequences from 23 superfamilies. Among these, the monotypic Lasiocampoidea is represented by four species in two genera. Considering that the monotypic superfamily consists of 1,952 species with five subfamilies (van Nieukerken et al., 2011), mitogenome sequences from additional diverse taxonomic groups could be required for mitogenome-based phylogenetic studies. In fact, recent large-scale mitogenome-based lepidopteran phylogenies only included a single genus or a single species (Timmermans et al., 2014; Ramírez-Ríos et al., 2016).

The lappet moth, Kunugia undans (Walker) (Lepidoptera: Lasiocampidae), is distributed in South Korea (excluding the far eastern Ulleungdo Island), far eastern Russia, Japan, and Australia (Park et al., 1999; Shin, 2001). In Korea, adults are found from September to October, eggs then overwinter, and larvae hatch in the spring (Park et al., 1999). Its host plants are Castanea crenata S. et Z., Quercus acutissima Carr., Quercus variabilis Bl. in Fagaceae, and Malus pumila var. dulcissima Koidz. in Rosaceae (Park et al., 1999). Variations in size, coloration, 
and lines on the wings are present. The wingspan of the species is 56-65 $\mathrm{mm}$ in males and 79-92 $\mathrm{mm}$ in females, and forewings have a small white spot at the medial cell (Shin, 2001).

In this study, we determined the complete mitogenome sequence of the lappet moth $K$. undans, adding a new mitogenome sequence of a previously unreported genus of Lasiocampoidea. The genomic characteristics of the sequence were compared to those of other lasiocampid species in terms of genome structure, genomic arrangement, nucleotide composition, codon usage, etc. Furthermore, to better understand the evolutionary characteristics of the Lasiocampoidea, including $K$. undans, the mitogenome sequences were compared to the representatives of the Macroheterocera clade, to which Lasiocampoidea belongs.

\section{Materials and Methods}

\section{DNA extraction, PCR and sequencing}

An adult $K$. undans was collected from Shinan-gun in Jeollanamdo Province in Korea (343' $60^{\prime}$ ' N, $125^{\circ} 6^{\prime} 50^{\prime}$ ', E) in 2009 . After collection in the field, the sample was prepared as a dried specimen and deposited at Chonnam National University, Gwangju, Korea under the accession code KTOL-Bom-27. DNA was extracted from the hind legs using a Wizard Genomic DNA Purification Kit, in accordance with the manufacturer's instructions (Promega, Madison, WI, USA). For whole mitogenome sequencing, primers that amplify three long overlapping fragments (LF1 from $C O I$ and ND4, LF2 from ND5 to $\operatorname{lr} R N A$, and LF3 from $\operatorname{lr} R A$ to $C O I$ ) were adapted from Kim et al. (2012).

Three long fragments (LFs) were amplified using LA $\mathrm{Taq}^{\mathrm{TM}}$ (Takara Biomedical, Tokyo, Japan) under the following conditions: $96^{\circ} \mathrm{C}$ for $2 \mathrm{~min} ; 30$ cycles of $98^{\circ} \mathrm{C}$ for $10 \mathrm{sec}$ and $48^{\circ} \mathrm{C}$ for $15 \mathrm{~min}$; and a final extension step of $72{ }^{\circ} \mathrm{C}$ for $10 \mathrm{~min}$. Using the LFs as templates, 26 overlapping short fragments (SF) were amplified using the primers adapted from Kim et al. (2012) and AccuPower ${ }^{\circledR}$ PCR PreMix (Bioneer, Daejeon, Korea). The PCR conditions for SFs were as follows: denaturation for $5 \mathrm{~min}$ at $94{ }^{\circ} \mathrm{C}$; 35 cycles of 1 min denaturation at $94{ }^{\circ} \mathrm{C} ; 1 \mathrm{~min}$ annealing at $48-51^{\circ} \mathrm{C} ; 1 \mathrm{~min}$ extension at $72^{\circ} \mathrm{C}$; and a final extension of $7 \mathrm{~min}$ at $72{ }^{\circ} \mathrm{C}$. Primers used to amplify and sequence the LFs and SFs are presented in Table S1. DNA sequencing was conducted using the ABI PRISM ${ }^{\circledR}$ BigDye ${ }^{\circledR}$ Terminator v3.1 Cycle Sequencing Kit and an ABI PRISMTM 3100 Genetic Analyzer (PE Applied Biosystems, Foster City, CA, USA). All products were sequenced from both directions.

\section{Gene annotation}

Individual SF sequences were assembled into the complete mitogenome using Seqman software (DNASTAR, Madison, Wisconsin, USA). Identification, boundary delimitation, and secondary structure folding of
tRNAs were performed using tRNAscan-SE 1.21 with the search mode set as default, the Mito/Chloroplast as the searching source, the genetic code of invertebrate mitogenomes for tRNA isotype prediction, and a cove score cut-off of 1 (Lowe and Eddy, 1997). Twenty-one tRNAs were detected based on these parameters. However, $\operatorname{trn} S_{1}$, which has a truncated DHU arm, was detected using a hand-drawn secondary structure in conjunction with an alignment of the predicted $\operatorname{trn} S_{I}$ regions of other lasiocampid species, and the anticodon was given particular consideration (Timmermans et al., 2014; Qin et al., 2015; Kim et al., 2016). Individual PCGs were identified, and a boundary was delimited using the blastx and tblastn programs in BLAST (http://blast.ncbi.nlm.nih.gov/BLAST.cgi). With the aid of sequences from other lasiocampid species, the start and stop codons of PCGs were confirmed using MAFFT ver. 6 (Katoh et al., 2002). Two rRNAs and the A+T-rich region were identified and delimited using the nucleotide blast algorithm in Blast, and it was further confirmed with the alignment of mitochondrial rRNA genes and sequences of the A+T-rich region of other lasiocampid species using MAFFT ver. 6.

\section{Comparative analysis}

For the comparative analysis of the $K$. undans mitogenome, available lasiocampid species and one species from each genus of the macroheteroceran superfamily were downloaded from either GenBank or AMiGA (Feijao et al., 2006), resulting in 11 mitogenome sequences from four Lasiocampidae species (including $K$. undans) and 48 species from five macroheteroceran superfamilies (Bombycoidea, Geometroidea, Noctuoidea, Drepanoidea, and Mimallonoidea). The nucleotide sequences of the PCGs were translated based on the invertebrate genetic code for mitochondrial DNA (mtDNA). Codon usage and nucleotide composition were determined by MEGA 6 (Tamura et al., 2013), and gene overlap and intergenic-space sequences were hand-counted. The A/T content of each gene, whole genome, and each codon position of the PCGs were calculated with DNASTAR (Madison, USA) (Burland, 2000). The $K$. undans sequence data were deposited to GenBank under accession no. KX822016.

\section{Results and Discussion}

\section{Mitogenome organization and composition}

The mitogenome size of $K$. undans is $15,570 \mathrm{bp}$, and is slightly larger than that of any other lasiocampid species, which range in size from $15,407 \mathrm{bp}$ in Dendrolimus punctatus (KJ913814) to 15,552 bp in Apatelopteryx phenax (KJ508055) (Table 1). K. undans contains 3,735 codons, excluding termination codons, and this number is the third largest in the sequenced Lasiocampoidea (next to D. spectabilis and A. phenax; Table 1). The size and codon 
counts of the lasiocampid species are well within the range found in macroheteroceran species, and no peculiarities associated with total size and codon count were detected in Lasiocampoidea (Table 1, Table S2).

Compared to the typical sets of genes and regions found in animal mitogenomes (13 PCGs, 22 tRNAs, 2 rRNA genes, and one non-coding A+T-rich region), the $K$. undans mitogenome contains one extra trnR, which is located in tandem to another $\operatorname{trn} R$ [referred to as $\operatorname{trn} R$ (A) for the copy located next to trnA and $\operatorname{trn} R$ (B) for the copy located next to $\operatorname{trn} N]$ between trnA and $\operatorname{trnN}$ (Figure 1). Pairwise sequence divergence between the two tRNAs was $10.94 \%$ (7 bp). Among lasiocampid species (data not shown), pairwise sequence divergence was 3.18-7.81\% and $10.94 \%$ compared to $\operatorname{trn} R(\mathrm{~A})$ and $\operatorname{trn} R(\mathrm{~B})$, respectively, indicating that $\operatorname{trn} R(\mathrm{~A})$ is more likely to be a functional copy, in that the sequence divergence range reflects the current taxonomic hierarchy. Nevertheless, both $\operatorname{trn} R$ copies have an identical anticodon (TCG) that is found in all other Lasiocampoidea (Table 2, Table S3), and they exhibit the proper secondary cloverleaf structure (Figure S1). Thus, the functionality of $\operatorname{trn} R$ (B) remains unknown. The tandem location of two $\operatorname{trn} R$ copies that exhibit proper secondary structures and an identical anticodon may indicate a gene duplication event rather than horizontal transfer (Higgs et al., 2003). In Lepidoptera, Coreana raphaelis (Papilionoidea) was the first species reported to have 23 tRNA genes instead of the usual 22 because of a tandemly duplicated $\operatorname{trn} S_{I}$ between $\operatorname{trnN}$ and trnE (Kim et al., 2006). Ctenoptilum vasava (Papilionoidea) was subsequently reported to have an extra trnS $S_{1}$ (Kim et al., 2006; Hao et al., 2012). However, the extra trnR found in the K. undans mitogenome is likely unique in Macroheterocera, in that our careful reexamination of all available lasiocampid species and all Macroheterocera did not reveal extra tRNAs (data not shown). Currently, the K. undans mitogenome is the only available Kunugia sequence, so whether this dupli-

Ancestral arrangement in insects

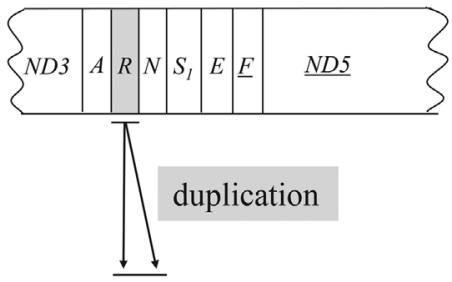

Kunugia undans arrangement

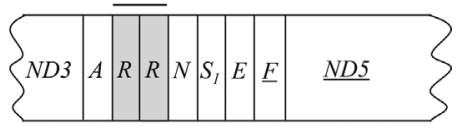

Figure 1 - Schematic illustration of the gene arrangement with the duplicated $\operatorname{trn} R$ detected in Kunugia undans. Gene sizes are not drawn to scale. Gene names that are not underlined indicate a forward transcriptional direction, whereas underlined sequences indicate a reversed transcriptional direction. tRNAs are denoted by one-letter symbols in accordance with the IUPAC-IUB single-letter amino acid codes. The remaining genes and gene order configurations that are identical to ancestral insects are omitted. 
Table 2 - Genomic summary of Kunugia undans.

\begin{tabular}{|c|c|c|c|c|}
\hline Gene & Anticodon & $\begin{array}{l}\text { Start } \\
\text { codon }\end{array}$ & $\begin{array}{l}\text { Stop } \\
\text { codon }\end{array}$ & $\begin{array}{c}\text { Nucleotide position } \\
\text { (size) }\end{array}$ \\
\hline $\operatorname{trn} M$ & CAT & - & - & $1-68(68)$ \\
\hline $\operatorname{trnI}$ & GAT & - & - & $72-135(64)$ \\
\hline$\underline{\operatorname{trn} Q}$ & TTG & - & - & $136-205(70)$ \\
\hline ND2 & & ATT & TAA & $263-1276(1014)$ \\
\hline $\operatorname{trn} W$ & TCA & - & - & $1275-1344(70)$ \\
\hline$\underline{\operatorname{trn} C}$ & GCA & - & - & $1337-1402(66)$ \\
\hline$\underline{\operatorname{trn} Y}$ & GTA & - & - & $1412-1479(68)$ \\
\hline$C O I$ & & CGA & T-tRNA & $1500-3057$ (1558) \\
\hline $\operatorname{trn} L_{2}$ & TAA & - & - & $3058-3125(67)$ \\
\hline COII & & ATA & T-tRNA & $3125-3806(682)$ \\
\hline $\operatorname{trn} K$ & CTT & - & - & $3807-3877(71)$ \\
\hline $\operatorname{trn} D$ & GTC & - & - & $3879-3947$ (69) \\
\hline$A T P 8$ & & ATC & TAA & $3948-4109$ (162) \\
\hline ATP6 & & ATG & TAA & $4103-4780(678)$ \\
\hline COIII & & ATG & TAA & $4787-5575(790)$ \\
\hline $\operatorname{trn} G$ & TCC & - & - & $5578-5644(67)$ \\
\hline ND3 & & ATC & TAA & $5645-5998(354)$ \\
\hline $\operatorname{trn} A$ & TGC & - & - & $6003-6070(68)$ \\
\hline $\operatorname{trn} R(\mathrm{~A})$ & $\mathrm{TCG}$ & - & - & $6084-6147(64)$ \\
\hline $\operatorname{trn} R(\mathrm{~B})$ & $\mathrm{TCG}$ & - & - & $6175-6241(67)$ \\
\hline $\operatorname{trn} N$ & GTT & - & - & $6242-6308(67)$ \\
\hline $\operatorname{trn} S_{1}$ & GCT & - & - & $6308-6375(68)$ \\
\hline $\operatorname{trn} E$ & TTC & - & - & $6376-6440(65)$ \\
\hline$\underline{\operatorname{trn} F}$ & GAA & - & - & $6471-6537(67)$ \\
\hline$\underline{N D 5}$ & & ATT & T-tRNA & $6538-8275(1738)$ \\
\hline$\underline{\operatorname{trnH}}$ & GTG & - & - & $8276-8343(68)$ \\
\hline$\underline{N D 4}$ & & ATG & TAG & $8348-9682(1335)$ \\
\hline$\underline{N D 4 L}$ & & ATG & TAG & 9688-9981 (294) \\
\hline $\operatorname{trn} T$ & TGT & - & - & $9986-10050(65)$ \\
\hline$\underline{\operatorname{trn} P}$ & TGG & - & - & $10051-10115(65)$ \\
\hline ND6 & & ATA & TAA & 10124-10654 (531) \\
\hline$C y t B$ & & ATG & TAA & $10662-11807$ (1146) \\
\hline $\operatorname{trn} S_{2}$ & TGA & - & - & $11809-11875(67)$ \\
\hline$\underline{N D 1}$ & & ATG & TAA & $11869-12825$ (957) \\
\hline$\underline{\operatorname{trn} L_{1}}$ & TAG & - & - & $12827-12892(66)$ \\
\hline$\underline{\operatorname{lrRNA}}$ & & - & - & $12893-14406(1513)$ \\
\hline$\underline{\operatorname{trn} V}$ & TAC & - & - & $14407-14471(65)$ \\
\hline$\underline{s r R N A}$ & & - & - & $14472-15253(782)$ \\
\hline $\begin{array}{l}\mathrm{A}+\mathrm{T}-\text { rich } \\
\text { region }\end{array}$ & & - & - & $15254-15570(317)$ \\
\hline
\end{tabular}

tRNA abbreviations follow the IUPAC-IUB three letter code. -, not applicable.

cation event was species- or genus-specific is an intriguing question.

The A/T nucleotide composition of the whole genome was $78.64 \%$ in $K$. undans, indicating biased A/T nucleotides, but it represents the lowest percentage detected in lasiocampid species (Table 1). Among macroheteroceran superfamilies, the A/T composition of the whole mitogenome in Lasiocampoidea is slightly lower than that of any other macroheteroceran superfamily $(79.47 \%$ vs $80.23-80.79 \%$ ), but the difference is slight (Table S2). The
A/T content among $K$. undans genes varied between RNA $(86.06 \%$ in $\operatorname{srRNA}, 83.29 \%$ in $\operatorname{lr} R N A$, and $81.54 \%$ in tRNAs) and PCG (76.64\%) genes, and the same trend was also found in other sequenced Macroheterocera, including Lasiocampoidea (Table 1, Table S2).

The $K$. undans gene arrangement is identical to that of other ditrysian Lepidoptera that exhibit the $\operatorname{trn} M-\operatorname{trn} I$ - $\operatorname{trn} Q$ order (where the underline indicates a gene inversion) at the $\mathrm{A}+\mathrm{T}$-rich region and ND2 junction, with the exception of the duplicated trnR (Table 2; Kim et al., 2011; Timmermans et al., 2014; Park et al., 2016; Zhao et al., 2016). This arrangement is found in all sequenced Macroheterocera (Park et al., 2016), including Lasiocampoidea (Table 2; Table S3). However, it differs from the ancestral $\operatorname{trnI-\operatorname {trn}Q-}$ $\operatorname{trn} M$ order found in the majority of insects and the lepidopteran superfamilies Hepialoidea and Nepticuloidea, which are ancient, non-ditrysian lepidopteran groups (Cao et al., 2012; Timmermans et al., 2014). Thus, this tRNA rearrangement has been regarded as synapomorphy for Ditrysia. However, a new arrangement, trnI-trnM-trnQ, was reported from a butterfly species belonging to Nymphalidae in Papilionoidea (Xuan et al., 2016). Therefore, the latter arrangement might represent an autapomorphy, in that no other congeneric species has the arrangement (Park et al., 2016).

\section{Genes}

Twelve of the $13 \mathrm{~K}$. undans PCGs started with ATN, but $C O I$ started with an alternative CGA start codon, as observed in other moths (Figure S2). There is no typical start codon at the 5'-end of $\operatorname{trn} Y$ and the intergenic spacer sequence located between $\operatorname{trn} Y$ and $C O I$, so CGA is the only possible start codon for COI in K. undans. The CGA start codon is found in all other sequenced macroheteroceran superfamilies, but some authors designate the typical ATN codon as the start codon for COI (Figure S2). This start codon has been reported to be highly conserved at the start region of $\mathrm{COI}$ in other Lepidoptera, and it was confirmed in a species of Lepidoptera based on expressed sequence tag data (Margam et al., 2011; Kim et al., 2014; Park et al., 2016). Thus, the presence of a CGA start codon is now considered a synapomorphic trait in Lepidoptera, although some exceptions exist. The mitochondrial PCGs available for Lasiocampoidea, including $K$. undans, ended with TAA in the majority of PCGs, but they also infrequently ended with a single $\mathrm{T}$ (Table 2; Table S3). The TAG stop codon was uniquely used in $K$. undans for ND4 and ND4L, while other lasiocampid species used a single T for ND4 and TAA for ND4L (Table 2; Table S3). The incomplete termination codon is known to result in a complete TAA stop codon via posttranslational modifications that occur during the mRNA maturation process (Ojala et al., 1981).

The biased A/T content was reflected in the form of codon usage. For instance, among the 64 available codons, the most frequently used codons [TTA (leucine), ATT 
(isoleucine), TTT (phenylalanine), and ATA (methionine)] accounted for $37.2 \%$ in $K$. undans, and this value was the lowest frequency detected in Lasiocampoidea (Table 3). These four codons are all comprised of A or T nucleotides, thus indicating the biased usage of $\mathrm{A} / \mathrm{T}$ nucleotides in Lasiocampoidea PCGs, including $K$. undans. Other macroheteroceran superfamilies have also shown a similar pattern, revealing 39.1-40.7\% in Bombycoidea, 37.5-40.4\% in Geometroidea, 38.0-44.6\% in Noctuoidea, 40.8-40.9\% in Drepanoidea, and 39.3\% in Mimallonoidea (Table S4).

The nucleotide composition of the 13 concatenated PCGs in the $K$. undans mitogenome was $33.5,43.2,11.8$, and $11.5 \%$ for adenine, thymine, cytosine, and guanine, respectively, indicating A/T bias (Table 4). The base composition at each codon position of the $K$. undans PCGs indicated that the third codon position $(86.5 \%)$ had a substantially higher $\mathrm{A} / \mathrm{T}$ content than the first $(72.6 \%)$ and second $(70.4 \%)$ codon positions. A similar pattern was detected in other sequenced Lasiocampoidea, with averages of 77.6, 73.0, and 89.0 in the first, second, and third positions, respectively (Table 4).

Two rRNA genes in $K$. undans, $\operatorname{lr} R N A$ and $\operatorname{srRNA}$, were of 1,514 and $782 \mathrm{bp}$, respectively, (Table 2), and the sizes of the two genes in $K$. undans were larger than those of any found in other lasiocampid species, which ranged from 1,346 bp (A. phenax) to 1,452 bp (D. punctatus) in $\operatorname{lrRNA}$ and $747 \mathrm{bp}$ (A. phenax) to $780 \mathrm{bp}$ (D. punctatus) in srRNA (Table S2). tRNA sizes ranged from $64 \mathrm{bp}(t r n I)$ to 71 bp $(\operatorname{trn} K)$ in $K$. undans, and similar size ranges were found in other sequenced lasiocampid species (Table 2; Table S3). All $K$. undans tRNAs possessed invariable lengths of $7 \mathrm{bp}$ for the aminoacyl stem, $7 \mathrm{bp}$ for the anticodon loop, and $5 \mathrm{bp}$ for the anticodon stem (Figure S1), and most tRNA size variation resulted from length variations in the DHU and T $\Psi \mathrm{C}$ arms. For instance, $\operatorname{trn} S_{1}$ has an atypical cloverleaf secondary structure that lacked the DHU stem, but the remaining $K$. undans tRNAs formed the typical secondary cloverleaf structure (Figure S1). The aberrant $\operatorname{trn} S_{1}$ has been reported in many metazoan species, including insects (Garey and Wolstenholme, 1989; Wolstenholme, 1992). The DHU stem and loop are involved in tertiary interactions required for the proper folding and functioning of tRNA (Rich and RajBhandary, 1976). Thus, an atypical secondary structure may hamper the functionality of tRNA, but a nuclear magnetic resonance analysis from nematodes demonstrated that the aberrant $\operatorname{trn} S_{1}$ also was functionally similar to typical tRNAs based on structural adjustments required to ensure ribosome fitting (Ohtsuki et al., 2002).

\section{The A+T-rich region}

The length of the A+T-rich region in $K$. undans was $317 \mathrm{bp}$, and A/T nucleotides made up $88.64 \%$ of the sequence (Table 2). This region contained the highest $\mathrm{A} / \mathrm{T}$ content of any region of the $K$. undans mitogenome (Table $1)$. Moreover, this region was the shortest in length, and it contained the least $\mathrm{A} / \mathrm{T}$ nucleotides among lasiocampid species (Table 2, Table S3).

The insect A+T-rich region harbors signals for replication and transcription initiation, so it is known to have conserved sequences in the region, which are in the form of conserved sequence blocks (Fauron and Wolstenholme, 1980; Clary and Wolstenholme, 1987; Saito et al., 2005). In

Table 3 - Frequency of the four most frequently used codons in Lasiocampoidea.

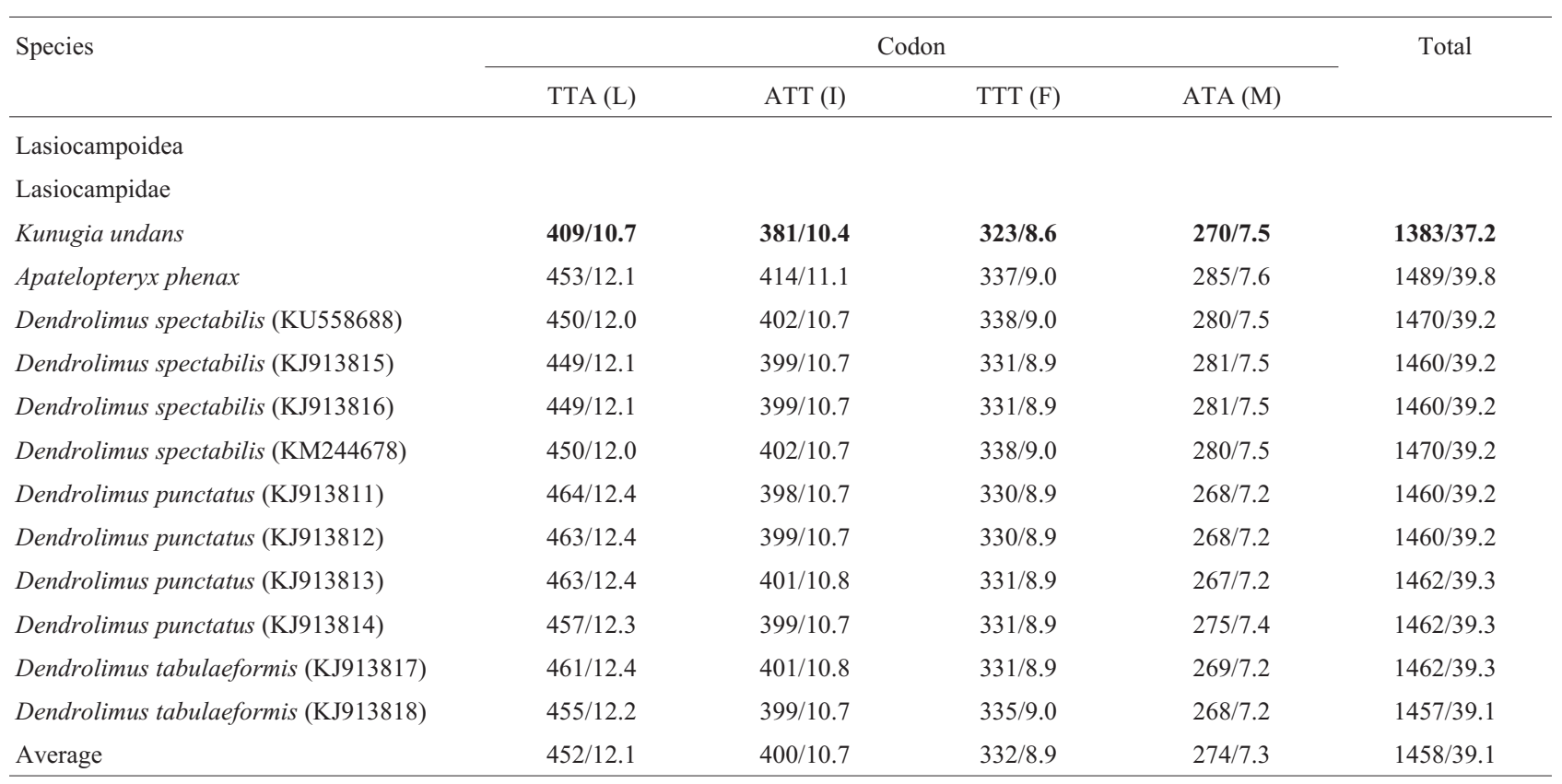

The corresponding amino acids are located in parentheses. Values after the backslash indicate the percentage of corresponding codons. 


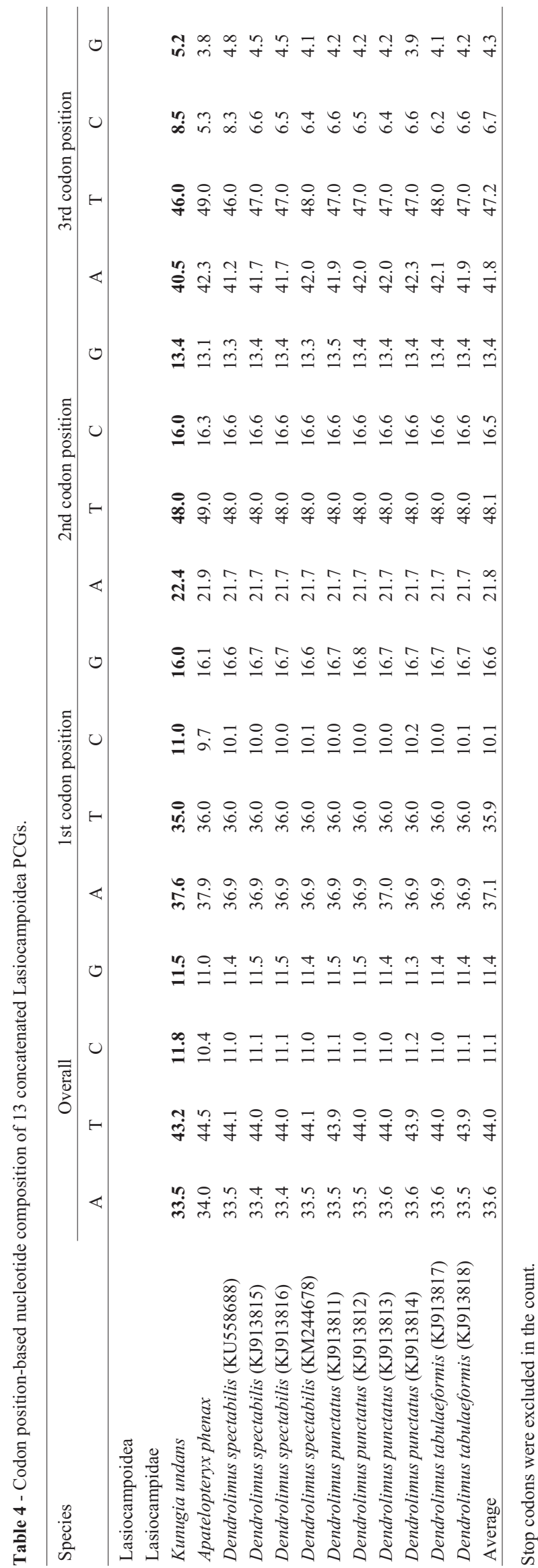

fact, previous studies revealed several conserved blocks in a substantial number of lepidopteran groups (Liao et al., 2010; Kim et al., 2014), and a search for the A+T-rich region of lasiocampid species (including $K$. undans) resulted in the detection of several conserved sequences (Figure 2). The first conserved sequence, which is located close to the 5 '-end of the $\operatorname{SrRNA}$, is the ATAGA motif followed by a poly-T stretch of varying length. The $K$. undans $\mathrm{A}+\mathrm{T}$-rich region contained a 14-bp T stretch that was upstream of the 5 '-end of the srRNA (Figure 2), and this poly-T stretch is well-conserved in all sequenced lasiocampid (ranging in size from $12 \mathrm{bp}$ to $14 \mathrm{bp}$; Figure 2) and macroheteroceran species (Figure S3). Saito et al. (2005) previously reported for the Bombyx mori mitogenome the precise position of the replication origin for minor-strand mtDNA, which is immediately downstream of a poly-T stretch that is located upstream of the $\operatorname{sr} R N A 5^{\prime}$ '-end. Thus, this poly-T stretch is thought to function as a possible recognition site for the initiation of replication of the minor mtDNA strand. Additionally, another conserved motif ATAGA is located immediately downstream of the poly-T stretch, and it is very well-conserved in all sequenced lasiocampid species, including K. undans (Figure 2) and macroheteroceran species (Figure S3). A previously suggested function of this motif is a regulatory role in conjunction with the poly- $\mathrm{T}$ stretch, but experimental data are required to support this hypothesis (Kim et al., 2009). Excluding the previously described sequences, there are only a few additional conserved sequences in the $\mathrm{A}+\mathrm{T}$-rich region of lasiocampid [e.g., K. undans (Figure 2)] and macroheteroceran species (Figure S3), including two or more ATTTA sequences scattered in the A+T-rich region, a microsatellite-like TA repeat, and a poly-T stretch. Our careful reexamination of the $\mathrm{A}+\mathrm{T}$-rich regions of macroheteroceran species resulted in the detection of repeat sequences in several species, including two of each 55-bp and 24-bp repeats in Bombyx huttoni (Bombycoidea); six 26-bp and two 18-bp repeats in Phthonandria atrilineata, two 278-bp repeats in Dysstroma truncata, four 24-bp repeats in Operophtera brumata (Geometroidea), two 16-bp repeats in Agrotis ipsilon, and two 11-bp repeats in Risoba prominens (Noctuoidea) (Yang et al., 2009; Timmermans et al., 2014; Derks et al., 2015; Wu et al., 2015; Yang et al., 2015; Peng et al., 2016). Nevertheless, repeat sequences that were longer than $10 \mathrm{bp}$ were not detected in sequenced lasiocampid species, including $K$. undans.

\section{Non-coding sequences}

Excluding the A+T-rich region, the $K$. undans mitogenome has non-coding sequences that total $172 \mathrm{bp}$ (with a range of 1-57 bp) and spread over 17 regions (Table 2). Comparison of available lasiocampid species indicated that intergenic spacing patterns and sizes are largely consistent in Lasiocampoidea, including those of $K$. undans. In particular, the 57-bp spacer found at the $\operatorname{trn} Q$ and $N D 2$ junction 


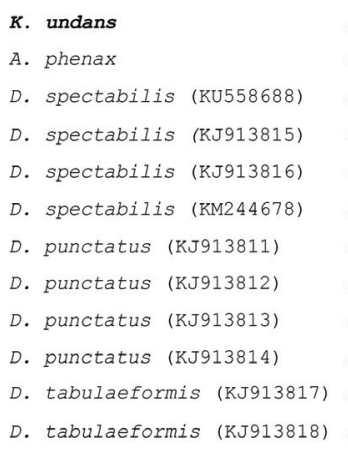

\begin{tabular}{|c|c|c|c|c|c|c|c|c|}
\hline$\leftarrow$ & & $\begin{array}{l}\text { ATAGA } \\
\text { motif }\end{array}$ & $\begin{array}{l}\text { poly-T } \\
\text { stretch }\end{array}$ & $\begin{array}{c}\text { ATTTA } \\
\text { sequence }\end{array}$ & $\begin{array}{l}\text { TA } \\
\text { repeat }\end{array}$ & $\begin{array}{c}\text { ATTTA } \\
\text { sequence }\end{array}$ & & $\rightarrow$ \\
\hline SrRNA & $15254-$ & -ATAGA & 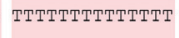 & -ATTTA & $\cdots(T A)_{7}$ & ATTTA & -15570 & $\operatorname{trn} M$ \\
\hline SrRNA & $15095-$ & ATAGA & -TITTITTTITTTT & $\cdot \operatorname{ATTTA} \cdot(T A)_{11} \cdot(T A)_{5}(T A)_{5}$ & & -ATTTA & -15552 & $\operatorname{trn} M$ \\
\hline srRNA & $15090-$ & -ATAGA & 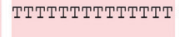 & -АТTTA $\cdots \cdots \cdots \cdots$ & $\cdots(T A)_{7} \cdot$ & -АTTTA & -15490 & $\operatorname{trn} M$ \\
\hline SrRNA & $15093-$ & ATAGA & TITTTITTTTTTTT & - ATTTA & $\cdots(T A)_{7}$ & -ATTTA & -15412 & $\operatorname{trn} M$ \\
\hline SrRNA & 15091 - & -ATAGA & 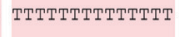 & - ATTTA & $\cdot(\mathrm{TA})_{7}$ & -ATTTA & -15410 & $\operatorname{trnM}$ \\
\hline srRNA & $15391-$ & -ATAGA & TITTTTTTTTTTTт & - ATTTA & $\cdot(T A)_{7}$ & - ATTTA & -444 & $\operatorname{trn} M$ \\
\hline SrRNA & $15100-$ & $\cdots$ ATAGA & TTTTITTTTTT & -ATTTA & $\cdot(T A)_{7}$ & -ATTTA & -15419 & $\operatorname{trn} M$ \\
\hline srRNA & $15099-$ & -ATAGA & TTTTTTTTTTTT & - ATTTA & $\cdots(T A)_{7}$ & - ATTTA & -15418 & $\operatorname{trn} M$ \\
\hline SrRNA & $15092-$ & -ATAGA & TTTTTTTTTTT & -ATTTA & $\cdots(T A)_{7}$ & -ATTTA & -15411 & $\operatorname{trn} M$ \\
\hline SrRNA & $15088-$ & -ATAGA & TTTTTTTTTTT & $\cdot \operatorname{ATTTA} \cdots \cdot$ & $\cdots(T A)_{7}$ & $\cdot$ ATTTA & -15407 & $\operatorname{trn} M$ \\
\hline srRNA & $15092-$ & -ATAGA & TTTтTтTтTтT. & -ATTTA & $\cdots(T A)_{7}$ & -ATTTA & -15411 & $\operatorname{trn} M$ \\
\hline SrRNA & $15090-$ & -ATAGA & TAтTтTтTтTт & -ATTTA & $\cdot(T A)_{7} \cdot$ & -ATTTA & -15409 & $\operatorname{trn} M$ \\
\hline
\end{tabular}

Figure 2 - Schematic illustration of the A+T-rich region of Lasiocampoidea, including Kunugia undans. The colored nucleotides indicate conserved sequences such as the ATAGA motif, poly-T stretch, ATTTA sequence, and microsatellite-like TA repeat sequences. Dots between sequences indicate omitted sequences, and arrows indicate the transcriptional direction. Subscripts indicate the repeat number. GenBank accession numbers of the species represented by more than one mitogenome sequence are enclosed in parentheses.

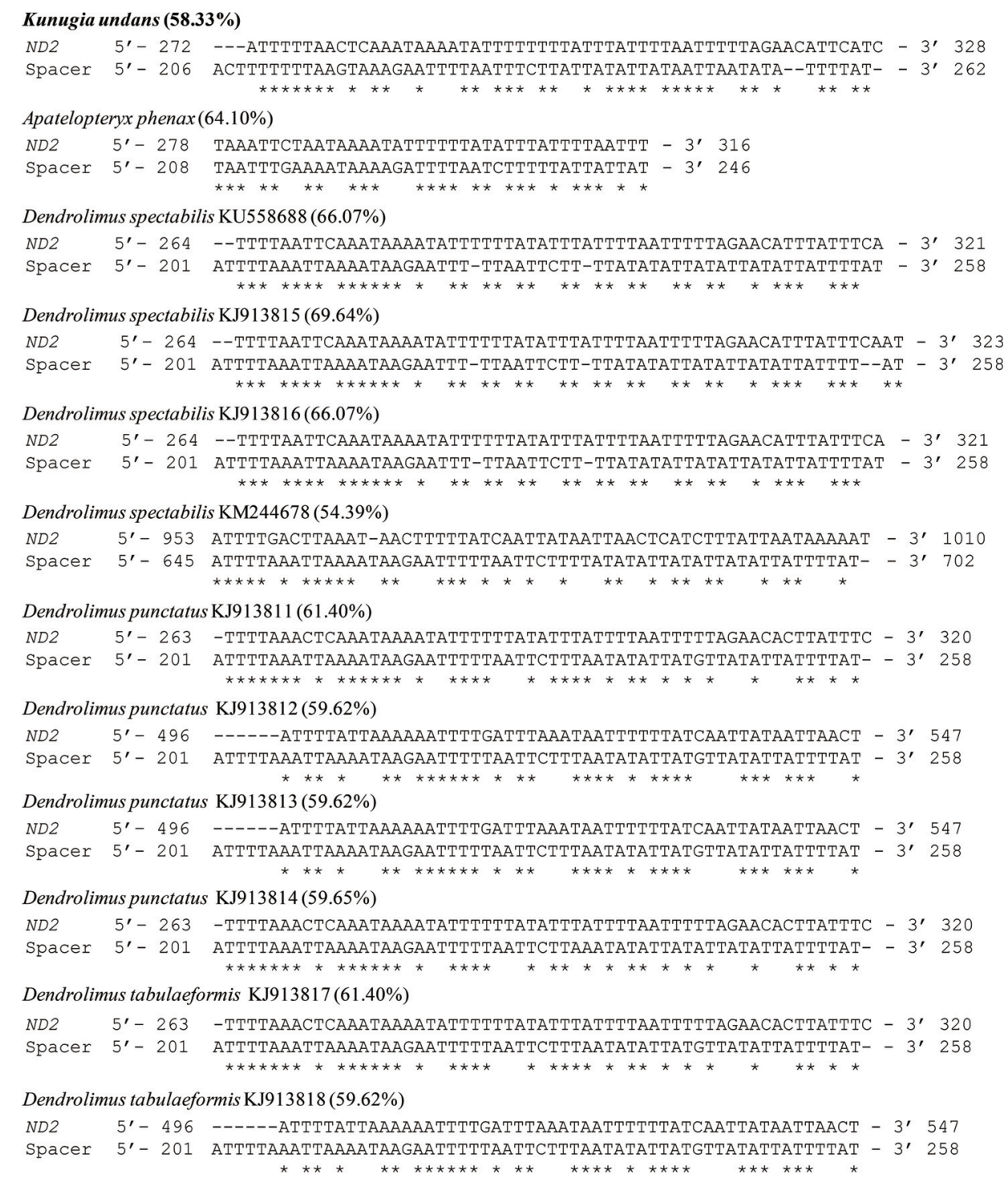

Figure 3 - Alignment of the spacer sequence (located between $\operatorname{trn} Q$ and ND2) and the neighboring partial ND2 of Lasiocampoidea, including Kunugia undans. Asterisks indicate consensus sequences in the alignment. Sequence homology between the spacer and ND2 is shown in the parentheses next to the species name and GenBank accession numbers of species represented by more than one mitogenome sequences. The beginning and end nucleotide positions of the sequences are indicated. 


\section{Lasiocampoidea \\ Kunugia undans Apatelopteryx phenax \\ D. spectabilis (KU558688) \\ D. spectabilis (KJ913815) \\ D. spectabilis (KJ913816) \\ D. spectabilis (KM244678) \\ D. punctatus (KJ913811) \\ D. punctatus (KJ913812) \\ D. punctatus (KJ913813) \\ D. punctatus (KJ913814) \\ D. tabulaeformis (KJ913817) \\ D. tabulaeformis (KJ913818)}

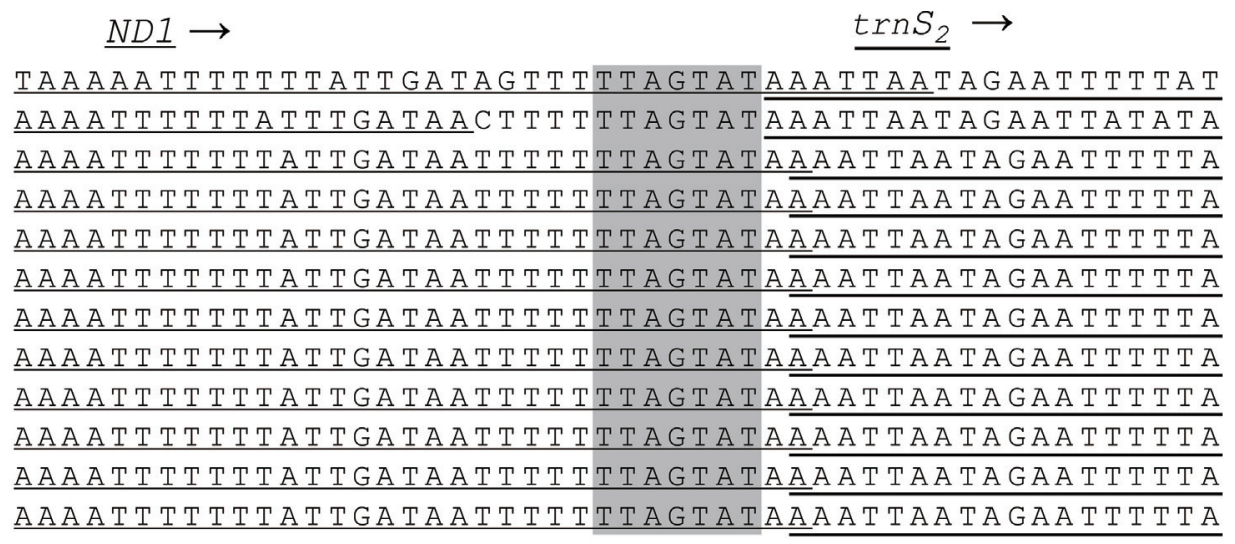

Figure 4 - Alignment of the internal spacer sequence located between $N D 1$ and $t r n S_{2}$ of Lasiocampoidea, including Kunugia undans. The shaded nucleotides indicate the conserved heptanucleotide (TTAGTAT) region. Underlined nucleotides indicate the adjacent partial sequences of $N D 1$ and $t r n S_{2}$. Arrows indicate the transcriptional direction.

(with a range of $39-58 \mathrm{bp}$ ) is consistently found in all lasiocampid species, including $K$. undans (Figure 3 ). The origin of this spacer region has previously been ascribed to the partial duplication and random loss of $N D 2$, leaving the current length of the spacer sequence at the $\operatorname{trn} Q$ and $N D 2$ junction because the spacer exhibited sequence identity to the neighboring $N D 2$, despite the fact that its non-coding nature may have allowed the spacer to diverge from the original ND2 (Kim et al., 2014). Regarding K. undans, the sequence identity of the spacer to the neighboring ND2 was $58.33 \%$ (Figure 3 ) and over $50.60 \%$ in 59 species of macroheteroceran superfamilies (Figure S4).

Other relatively long spacer sequences were found in several regions of lasiocampid species, including $K$. undans, including those at the $\operatorname{trn} Y$ and $C O I$ junction (20-34 bp), at the $\operatorname{trn} A$ and $\operatorname{trnR}$ junction (13-20 bp), at the $\operatorname{trnN}$ and $\operatorname{trn} S_{1}$ junction (11-21 bp, excluding $K$. undans that has a 1-bp overlap), and at the ND4 and ND4L junction (5-24 bp, excluding A. phenax that has a 5-bp overlap) (Table 2, Table S3). These spacer sequences are mainly composed of $\mathrm{A} / \mathrm{T}$ nucleotides that are often found within multiple runs of either T or A nucleotides (data not shown). Sequence alignment beyond the species level was nearly impossible due to considerable variability in length, sequence composition, and insertions/deletions (data not shown). The majority of the remaining spacer regions were short, with a few exceptions (e.g., less than 10 bp).

In previous lepidopteran mitogenomic studies, other spacer sequences at the trnS $S_{2}$ and ND1 junction were consistently reported in lepidopteran lineages (Cameron and Whiting, 2008; Kim et al., 2010; Yang et al., 2013; Kim et al., 2014; Park et al., 2016). The important feature of this spacer is the presence of a short-length TTAGTAT motif within the spacer sequence, which is thought to be a possible binding site for the transcription termination peptide of mtDNA (mtTERM). This characterization is based on the fact that the spacer is located after the final major-strand coded $C y t B$ (Taanman, 1999; Cameron and Whiting,
2008). Regarding $K$. undans, there is a 7-bp overlap at the $N D 1$ and $t r n S_{2}$ junction, but $K$. undans clearly possesses the same sequence motif (Figure 4). All other lasiocampid species, with the exception of $A$. phenax, have a 1-bp gene overlap in this region, but they also contain the 7-bp motif at the $N D 1$ and $\operatorname{trn} S_{2}$ junction. On the other hand, $A$. phenax has an intergenic spacer sequence at $12 \mathrm{bp}$, which includes the 7-bp motif. In other macroheteroceran species, the 7-bp motif is found in nearly all species without modification, with the exception of one Noctuoidea species, which has ATAGTAT instead of TTAGTAT. In Macroheterocera, the 7-bp motif is nearly always located at the spacer instead of the coding region at the $N D 1$ and $t r n S_{2}$ junction (Figure S5). Thus, the spacing pattern of Lasiocampoidea differs from that of other macroheteroceran superfamilies in this region, so mRNA expression data would be required to clarify the extension of $N D 1$ at the $N D 1$ and $\operatorname{trn} S_{2}$ junction.

In summary, in addition to the typical set of genes, the 15,570-bp complete mitogenome sequence of $K$. undans has an extra $\operatorname{trnR}$. The presence of the additional tRNA is unique in Macroheterocera, including Lasiocampoidea. The A+T-rich region of $K$. undans possesses a few conserved sequences, which were previously reported in other Macroheterocera (including Lasiocampoidea). Moreover, the intergenic spacing pattern and size for $K$. undans are largely consistent with those of other Macroheterocera (including Lasiocampoidea), but instead of an intergenic spacer, Lasiocampoidea (including $K$. undans) exhibit an overlap at the $\operatorname{trn} S_{2}$ and $N D 1$ junction.

\section{Acknowledgments}

This study was supported by the Basic Science Research Program through the National Research Foundation of Korea (NRF) funded by the Ministry of Education, Science, and Technology (2015R1D1A3A03018119). 


\section{References}

Burland TG (2000) DNASTAR's laser gene sequence analysis software. In: Misener S and Krawets SA (eds) Bioinformatics Methods and Protocols. Humana Press, Totowa, pp 71-91.

Cameron SL (2014) Insect mitochondrial genomics: implications for evolution and phylogeny. Annu Rev Entomol 59:95-117.

Cameron SL and Whiting MF (2008) The complete mitochondrial genome of the tobacco hornworm, Manduca sexta, (Insecta: Lepidoptera: Sphingidae) and an examination of mitochondrial gene variability within butterflies and moths. Gene 408:112-123.

Cao YQ, Ma C, Chen JY and Yang DR (2012) The complete mitochondrial genomes of two ghost moths, Thitarodes renzhiensis and Thitarodes yunnanensis: The ancestral gene arrangement in Lepidoptera. BMC Genomics 13:276.

Clary DO and Wolstenholme DR (1987) Drosophila mitochondrial DNA: Conserved sequences in the A + T-rich region and supporting evidence for a secondary structure model of the small ribosomal RNA. J Mol Evol 25:116-125.

Derks MFL, Smit S, Salis L, Schijlen E, Bossers A, Mateman C, Piji AS, de Ridder D, Groenen MAM, Visser ME, et al. (2015) The genome of winter moth (Operophtera brumata) provides a genomic perspective on sexual dimorphism and phenology. Genome Biol Evol 7:2321-2332.

Dowton M, Austin A, Dillon N and Bartowsky E (1997) Molecular phylogeny of the apocritan wasps: The Proctotrupomorpha and Evaniomorpha. Syst Entomol 22:245-255.

Fauron CM and Wolstenholme DR (1980) Intraspecific diversity of nucleotide sequences within the adenine+ thymine-rich region of mitochondrial DNA molecules of Drosophila mauritiana, Drosophila melanogaster and Drosophila simulans. Nucleic Acids Res 8:5391-5410.

Feijao PC, Neiva LS, Azeredo-Espin AML and Lessinger AC (2006) AMiGA: The arthropodan mitochondrial genomes accessible database. Bioinformatics 22:902-903.

Garey JR and Wolstenholme DR (1989) Platyhelminth mitochondrial DNA: Evidence for early evolutionary origin of a tRNA ${ }^{\text {ser }} \mathrm{AGN}$ that contains a dihydrouridine arm replacement loop, and of serine-specifying AGA and AGG codons. J Mol Evol 28:374-387.

Hao J, Sun Q, Zhao H, Sun X, Gai Y and Yang Q (2012) The complete mitochondrial genome of Ctenoptilum vasava (Lepidoptera: Hesperiidae: Pyrginae) and its phylogenetic implication. Comp Funct Genomics 2012:1-13.

Higgs PG, Jameson D, Jow H and Rattray M (2003) The evolution of tRNA-Leu genes in animal mitochondrial genomes. J Mol Evol 57:435-445.

Katoh K, Misawa K, Kuma K and Miyata T (2002) MAFFT: A novel method for rapid multiple sequence alignment based on fast Fourier transform. Nucleic Acids Res 30:3059-3066.

Kim I, Lee EM, Seol KY, Yun EY, Lee YB, Hwang JS and Jin BR (2006) The mitochondrial genome of the Korean hairstreak, Coreana raphaelis (Lepidoptera: Lycaenidae). Insect Mol Biol 15:217-225.

Kim JS, Park JS, Kim MJ, Kang PD, Kim SG, Jin BR, Han YS and Kim I (2012) Complete nucleotide sequence and organization of the mitochondrial genome of eri-silkworm, Samia cynthia ricini (Lepidoptera: Saturniidae). J Asia Pac Entomol 15:162-173.
Kim MJ, Wan X, Kim K-G, Hwang JS and Kim I (2010) Complete nucleotide sequence and organization of the mitogenome of endangered Eumenis autonoe (Lepidoptera: Nymphalidae). Afr J Biotechnol 9:735-754.

Kim MJ, Kang AR, Jeong HC, Kim K-G and Kim I (2011) Reconstructing intraordinal relationships in Lepidoptera using mitochondrial genome data with the description of two newly sequenced lycaenids, Spindasis takanonis and Protantigius superans (Lepidoptera: Lycaenidae). Mol Phylogenet Evol 61:436-445.

Kim MJ, Wang AR, Park JS and Kim I (2014) Complete mitochondrial genomes of five skippers (Lepidoptera: Hesperiidae) and phylogenetic reconstruction of Lepidoptera. Gene 549:97-112.

Kim MJ, Kim JS, Kim S-S, Kim SR and Kim I (2016) Complete mitochondrial genome of the pine moth Dendrolimus spectabilis (Lepidoptera: Lasiocampidae). Mitochondrial DNA Part B 1:180-181.

Kim SR, Kim MI, Hong MY, Kim KY, Kang PD, Hwang JS, Han YS, Jin BR and Kim I (2009) The complete mitogenome sequence of the Japanese oak silkmoth, Antheraea yamamai (Lepidoptera: Saturniidae). Mol Biol Rep 36:1871-1880.

Liao F, Wang L, Wu S, Li Y-P, Zhao L, Huang G-M, Niu C-J, Liu Y-Q and Li M-G (2010) The complete mitochondrial genome of the fall webworm, Hyphantria cunea (Lepidoptera: Arctiidae). Int J Biol Sci 6:172-186.

Lowe TM and Eddy SR (1997) TRNAscan-SE: A program for improved detection of transfer RNA genes in genomic sequence. Nucleic Acids Res 25:955-964.

Lu H-F, Su T-J, Luo AR, Zhu C-D and Wu C-S (2013) Characterization of the complete mitochondrion genome of diurnal moth Amata emma (Butler) (Lepidoptera: Erebidae) and its phylogenetic implications. PLoS One 8:e72410.

Mao M, Gibson T and Dowton M (2014) Evolutionary dynamics of the mitochondrial genome in the Evaniomorpha (Hymenoptera)-a group with an intermediate rate of gene rearrangement. Genome Biol Evol 6:1862-1874.

Mao M, Gibson T and Dowton M (2015) Higher-level phylogeny of the Hymenoptera inferred from mitochondrial genomes. Mol Phylogenet Evol 84:34-43.

Margam VM, Coates BS, Hellmich RL, Agunbiade T, Seufferheld MJ and Sun W (2011) Mitochondrial genome sequence and expression profiling for the legume pod borer Maruca vitrata (Lepidoptera: Crambidae). PLoS One 6:e16444.

Ohtsuki T, Kawai G and Watanabe K (2002) The minimal tRNA: Unique structure of Ascaris suum mitochondrial tRNASerUCU having a short $\mathrm{T}$ arm and lacking the entire $\mathrm{D}$ arm. FEBS Lett 514:37-43.

Ojala D, Montoya J and Attardi G (1981) tRNA punctuation model of RNA processing in human mitochondria. Nature 290:470-474.

Park JS, Kim MJ, Jeong SY, Kim SS and Kim I (2016) Complete mitochondrial genomes of two gelechioids, Mesophleps albilinella and Dichomeris ustalella (Lepidoptera: Gelechiidae), with a description of gene rearrangement in Lepidoptera. Curr Genet 62:809-826.

Park KT, Kim SS, Tshistjakov YA and Kwon YD (1999) Insect of Korea. Korea Research Institute of Bioscience and Biotechnology, and the Center for Insect Systematics, Chunchon, $358 \mathrm{p}$. 
Peng XY, Zhou P, Qiang Y and Qian ZQ (2016) Characterization of the complete mitochondrial genome of Bombyx huttoni (Lepidoptera: Bombycidae). Mitochondrial DNA A DNA Mapp Seq Anal 27:4112-4113.

Qin J, Zhang Y, Zhou X, Kong X, Wei S, Ward RD and Zhang A (2015) Mitochondrial phylogenomics and genetic relationships of closely related pine moth (Lasiocampidae: Dendrolimus) species in China, using whole mitochondrial genomes. BMC Genomics 16:428-439.

Ramírez-Ríos V, Franco-Sierra ND, Alvarez JC, SaldamandoBenjumea CI and Villanueva-Mejía DF (2016) Mitochondrial genome characterization of Tecia solanivora (Lepidoptera: Gelechiidae) and its phylogenetic relationship with other lepidopteran insects. Gene 581:107-116.

Rich A and RajBhandary UL (1976) Transfer RNA: Molecular structure, sequence, and properties. Annu Rev Biochem 45:805-860.

Saito S, Tamura K and Aotsuka T (2005) Replication origin of mitochondrial DNA in insects. Genetics 171:1695-1705.

Shin YH (2001) Coloured Illustrations of the Moths of Korea. Academybook Publishing Co. Ltd., Seoul, 551 p.

Taanman JW (1999) The mitochondrial genome: Structure, transcription, translation and replication. Biochim Biophys Acta 1410:103-123.

Tamura K, Stecher G, Peterson D, Filipski A and Kumar S (2013) MEGA6: Molecular Evolutionary Genetics Analysis ver. 6.0. Mol Biol Evol 30:2725-2729.

Tang M, Tan M, Meng G, Yang S, Su X, Liu S, Song W, Li Y, Wu Q, Zhang A, et al. (2014) Multiplex sequencing of pooled mitochondrial genomes-a crucial step toward biodiversity analysis using mito-metagenomics. Nucleic Acids Res 42:e166.

Timmermans MJ, Lees DC, Thompson MJ, Sáfián SZ and Brattström O (2014) Towards a mitogenomic phylogeny of Lepidoptera. Mol Phylogenet Evol 79:169-178.

van Nieukerken EJ, Kaila L, Kitching IJ, Kristensen NP, Lees DJ, Minet J, Mitter J, Mutanen M, Regier JC, Simonsen TJ, et al. (2011) Order Lepidoptera Linnaeus, 1758. Zootaxa 3148:212-221.

Wan X, Kim MJ and Kim I (2013) Description of new mitochondrial genomes (Spodoptera litura, Noctuoidea and Cnaphalocrocis medinalis, Pyraloidea) and phylogenetic reconstruction of lepidoptera with the comment on optimization schemes. Mol Biol Rep 40:6333-6349.

Wolstenholme DR (1992) Animal mitochondrial DNA: Structure and evolution. Int Rev Cytol 141:173-216.

Wu QL, Cui WX and Wei SJ (2015) Characterization of the complete mitochondrial genome of the black cutworm Agrotis ipsilon (Lepidoptera: Noctuidae). Mitochondrial DNA 26:139-140.

Xuan S, Song F, Cao L, Wang J, Li H and Cao T (2016) The complete mitochondrial genome of the butterfly Euripus nyctelius (Lepidoptera: Nymphalidae). Mitochondrial DNA A DNA Mapp Seq Anal 27:2563-2565.

Yang L, Wei ZJ, Hong GY, Jiang ST and Wen LP (2009) The complete nucleotide sequence of the mitochondrial genome of Phthonandria atrilineata (Lepidoptera: Geometridae). Mol Biol Rep 36:1441-1449.

Yang X, Xue D and Han H (2013) The complete mitochondrial genome of Biston panterinaria (Lepidoptera: Geometridae), with phylogenetic utility of mitochondrial genome in Lepidoptera. Gene 515:349-358.

Yang X, Cameron SL, Lees DC, Xue D and Han H (2015) A mitochondrial genome phylogeny of owlet moths (Lepidoptera: Noctuoidea), and examination of the utility of mitochondrial genomes for lepidopteran phylogenetics. Mol Phylogenet Evol 85:230-237.

Zhao J, Sun Y, Xiao L, Tan Y, Dai H and Bai L (2016) Complete mitochondrial genome of the pink bollworm Pectinophora gossypiella (Lepidoptera: Gelechiidae). Mitochondrial DNA A DNA Mapp Seq Anal 27:1575-1576.

\section{Internet Resources}

Basic Local Alignment Search Tool (BLAST), http://blast.ncbi.nlm.nih.gov/Blast.cgi (November 3, 2016).

\section{Supplementary material}

The following online material is available for this article: Table S1 - List of primers used to amplify and sequence the Kunugia undans mitogenome.

Table S2 - Characteristics of Macroheterocera mitogenomes.

Table S3 - Genomic summary of Lasiocampoidea.

Table S4 - Frequency of the four most frequently used codons in Macroheterocera.

Figure S1 - Predicted secondary cloverleaf structures for the 23 tRNA genes of Kunugia undans, with the duplicated $\operatorname{trnR}(\mathrm{A}$ and $\mathrm{B})$.

Figure S2 - Alignment of the initiation context of the Macroheterocera $\mathrm{COI}$.

Figure $\mathrm{S} 3$ - Schematic illustration of the $\mathrm{A}+\mathrm{T}$-rich region of Macroheterocera.

Figure S4 - Alignment of the spacer sequence (located between $\operatorname{trn} Q$ and ND2) and neighboring partial Macroheterocera ND2.

Figure S5 - Alignment of the internal spacer sequence located between $N D 1$ and $t r n S_{2}$ of Macroheterocera.

Associate Editor: Houtan Noushmehr

License information: This is an open-access article distributed under the terms of the Creative Commons Attribution License (type CC-BY), which permits unrestricted use, distribution and reproduction in any medium, provided the original article is properly cited. 